\title{
Developing A Framework For Land Management Based On Community Involvement In Ghana
}

Joshua Alabi, University of Professional Studies, Ghana Goski Alabi, University of Professional Studies, Ghana Ibrahim Mohammed, University of Professional Studies, Ghana

\begin{abstract}
Since the discovery of oil in commercial quantities in the Western Region of Ghana and the attendant media reports of some traditional leaders rushing to sell land, there has been a renewed interest in land management in the area. This paper investigated the involvement of traditional leaders in land management in the Western Region of Ghana and explored with participants possible ways of enhancing land management in Ghana. The study was conducted in the Districts and Municipal Assemblies along the coast of the Weston Region of Ghana using fifteen traditional leaders or Chiefs as the participants. A desk review of national policy documents on land management accompanied by interviews with the traditional leaders, show that Ghana abounds with laws and policies on land management as well as land use plans that provide for the involvement of traditional leaders. However, the results from our interviews with the selected traditional leaders mandated to be custodians of customary lands and by extension agents of lands management suggest that $92 \%$ are either unaware of the laws, policies, and plans or have limited knowledge about them. As a direct consequence of the lack of knowledge or paucity of knowledge about land use plans, these traditional leaders are not able to discharge rightfully their duty. The paper therefore concludes that traditional leaders require education on the national framework for land management in order to enhance their capacity for land management. It is therefore recommended that a centre should be established to provide relevant training and education to traditional leaders on land administration and management issues on a continual basis in the form of non-formal education.
\end{abstract}

Keywords: Land Management; Land Administration; Traditional Leadership; Western Region of Ghana

\section{INTRODUCTION}

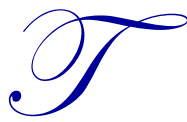

hroughout human history, societies have depended on and continue to depend on land and other natural resources for survival and livelihood. As a generic term in economics, land refers to all nature's gift to mankind. It goes beyond the soils and surface topography to include such features as the underlying superficial deposits, climate and water resources, and the plant and animal communities which have developed as a result of the interaction of these physical conditions (FAO \& UNEP, 1999). Land is considered as one of the four scarce economic resources whose demand outstrips its supply. As a scarce economic resource, land provides many socio-economic benefits to mankind: it provides sustenance and support to mankind as well as maintains all terrestrial ecosystems which are also of great benefits to mankind. Human beings continual dependence on the immense benefits of land makes it imperative to protect and manage it so that they can continue to derive maximum benefits from it without compromising on its benefits to the future generation.

Economists have argued that, when resources such as land are available in finite quantities to satisfy human wants, management of such limited resources becomes absolutely necessary. As such, we proceed to argue that the raison d'etre for land management is not only in the fact that it provides immense benefits to mankind, but also it is 
a scarce economic resource. Indeed, the literature on natural resources management also suggests that land needs to be managed because of its unique feature of non-renewable (or slowly-renewable) and the pressures exerted on it by the ever-increasing demand for it. In the presence of these two characteristics, natural resources literature argues that land tends to degenerate at a faster rate than its natural rate of regeneration (see FAO \& UNEP, 1999) and as such risk being depleted or rendered non-beneficial if not properly managed.

In line with the above thinking, human beings have demonstrated through history that in the early days of human settlement when population levels were low and grew slowly relative to the size and quality of land, land management was not an issue of major concern. What mattered to mankind at the time regarding land was purely land administration (i.e., determination of land rights and ownership, land valuation and use). In time, as human settlements expanded through population growth, there has been a rhythmic change in the thinking about land: interest in land has now stepped up from land administration to land management and sustainability. Tenure and security, valuation, and regulation which are the key components of land administration are no longer pursued as ends in themselves but means to an end. Industrialization, on the other part, has also contributed partially to the declining quality and high rate of degeneration of land and thereby adding impetus to the need for land management.

Using management literature, we define land management in this research as a process-driven function that ensures that land is put to good use at all times without compromising on its future benefits. For effective land management to take place, three ingredients are required: appropriate policies and enactments; institutions to administer the policies; and information infrastructure that will support land administration and management (Enemark, Williams, \& Wallace, 2005). Depending on how these ingredients are combined, various systems of land management may emerge. In Ghana, two systems of land management are run in tandem. These systems are known as state land management system and customary land management system. While state land management is the exclusive responsibility of the Lands Commission acting on behalf of the state, customary land management is the responsibility of institutions and structures designed for the customary administration of stool, skin, communityowned, or family lands. It is estimated that, about $80-90 \%$ of the undeveloped land in Ghana is managed by traditional authorities through customary laws and practices which are undocumented (Kasanga \& Kotey, 2001). It is worth noting that, the dual system of land management as it is being practiced currently in Ghana has its root in the forms of land ownership in Ghana - state-owned or customarily-owned.

In view of the existing dual system of land management, supplemented by the fact that traditional authorities are in control of the vast majority of the country's undeveloped land, it will be prudent to foster closer link and collaboration between the two major stakeholders: the custodians of the customary lands (in this case traditional leaders) and the established government institutions responsible for land management, particularly stateowned lands. It is even more important to foster closer collaboration between the traditional leaders and land sector agencies especially when there are media reports to suggest that some traditional leaders are not effectively managing their land to the benefit of their people on whose behalf they are holding the land in trust. This study was motivated by one such media report by Aboagye Boampong published on modernghana.com on $24^{\text {th }}$ September 2009. His report indicated that some traditional leaders in the Western Region of Ghana were rushing to sell vast expanse of lands just to cash in on land price hikes alleged to have been precipitated by the oil find in that region. The report further indicated that not only was this behaviour on the part of some of the chiefs at variant with the principles of sustainable development but could also disturb the relative peace the region was enjoying if not checked. Prior to Boampong's report, it was also reported in the news that the Western Regional House of Chiefs in the light of the oil find had issued a statement to chiefs in the region to desist from arbitrary sale of land that benefits them alone and not the people they represent. In the wake of all these clarion calls and the possible danger of landrelated conflicts, one major concern that remained in the minds of people was "how can the traditional leaders in the region be used to enhance the management of land."

As a first step to finding answer(s) to this question, the researchers speculated that, the existing policies and legislations are adequate to ensure proper land management. What is needed most is a deeper collaboration and reciprocal involvement of traditional leaders and the land sector agencies in the process. To find evidence in support of or against our proposition, our research questions were: (1) Are the traditional leaders in the Western Region aware of the existing national framework for land management in Ghana? (2) Do the traditional leaders know the institutions they are supposed to collaborate with in land management and the functions of those institutions? (3) 
What is the level of involvement traditional leaders in the existing framework for land management and to what extent are the traditional leaders also involving the land sector agencies in their function? Guided by these questions, the researchers sought to review the existing policy framework for managing land in Ghana and particularly in the Western Region with special interest on assessing the knowledge of traditional leaders about this framework and to gauge the extent of involvement of the traditional leaders in the land management process.

The rest of this paper is organised as follows: Section 2 presents the literature review and the conceptual framework adopted for this study; Section 3 presents the methodological issues; Section 4 presents the findings and discussion while the last section provides the conclusion and recommendations.

\section{LITERATURE REVIEW AND CONCEPTUAL FRAMEWORK}

Land administration and land management cannot be separated from each other. Land administration forms the infrastructure or backbone upon which land management strives (Kalantari, Rjabifard, \& Bennet, 2010). As matter of course, we cannot talk about land management without talking about land administration. In much the same way, we can hardly talk about land administration without linking it to land management as a means to an end.

In its embryonic stage, land administration was defined by three components: land ownership, land valuation, and land use. The ownership function of land administration focussed on establishing and protecting the right in land which included right of ownership, right to use, right to enjoy its produce, right to transfer, mortgage, or lease all of which must be exercised within the dictates of the law (Larsson, 1991). The valuation function of land administration on the other side involved the estimation of the worth of a land for purposes of setting the limit for sale and purchases of properties, setting rent, determining compensation for compulsory acquisition, asset accounting and management, lending and associated financial dealings, property settlements, property rating and taxation as well as property portfolio analysis (Britton \& Davies, 1980). In relation to land administration, land use was concerned about what land can be used for (UNECE, 2005).

Combining these three core functions of land administration, UNECE (1996) described land administration as the process of determining, recording, and disseminating information about the ownership, value, and use of land when implementing land management policies. UNECE (1996) however defined land management as the process by which a country's land resources are put into good effect. What constitutes a good effect remains open and could vary from one society to another. The World Bank (2006) explains that land management systems are supposed to maximize the social, economic, and environmental interests (benefits) in a way that is not damaging to the land but probably enhancing it. This exposition by the World Bank (2006) suggests that sustainable land management implies deriving maximum benefits from land without compromising the interest of future generation. Thus, preservation and improvement in the productive capacities of land resources while deriving maximum benefits from them are the watchwords for sustainable land management.

To put the relationship between land administration and land management into perspectives, land management is broader than land administration and it encapsulates all the principles and activities that will ensure sustainable development in the use of the land. Figure 1 below depicts the relationship between land administration and land management more precisely. 


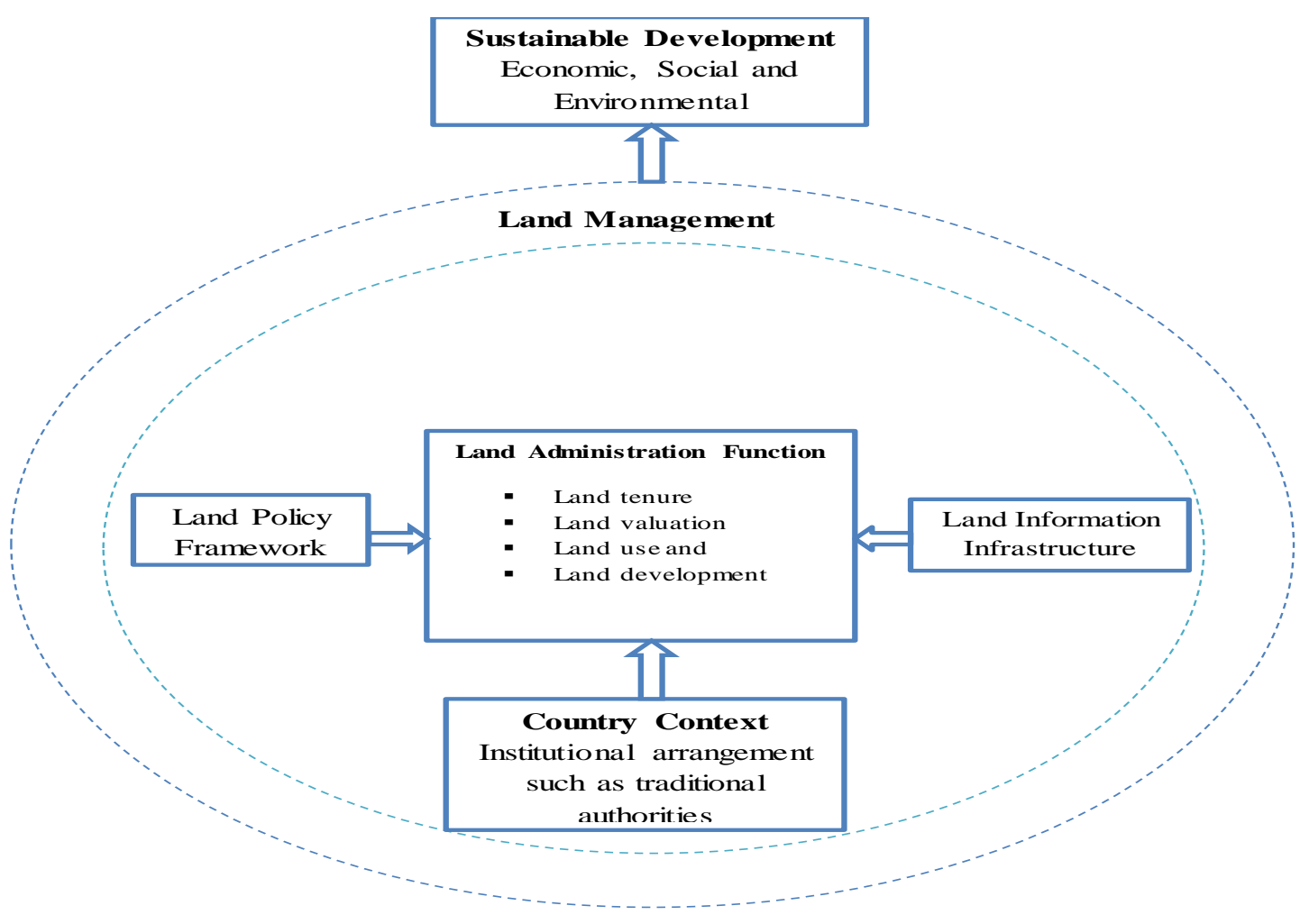

Figure 1: Relationship between Land Administration and Land Management Source: Developed by Researchers based on the land management paradigm provided by Enemark et al. (2005)

The above model suggests some important relationships. Significant among these and worthy of pointing out are that for land management to bring about sustainable development, it should be founded on a solid and comprehensive land administration. A comprehensive land administration should involve land tenure, land valuation, land use, and land development (Enemark, Williams, \& Wallace, 2005). In terms of land administration, the model also suggests three ingredients necessary for the effective delivery of land administration function. These are: appropriate land policies and legislations, administrative institutions and structures, and land information infrastructure. Land policies and legislations should set the agenda and broad framework for land administration and land management. The administrative institutions should implement or see to the implementation of the policies and legislations. Land information infrastructure provides necessary and up-to-date information on the land required.

The model also implies, albeit not directly, that effective implementation of land administration and for that matter land management will require inter-disciplinary skills that include legal, technical, economic, social, and environmental. Additionally, the model also suggests that land administration and land management is a group effort of all the relevant institutions. Like any system or process, a break-down in one part renders the other aspects ineffective.

\subsection{Conceptual Framework for Land Management}

Consistent with the model provided above, we define land management in this study as process-driven function involving many stakeholders (group efforts) aimed at putting land to good use at all times without compromising on its future benefits but probably enhancing it. With this definition, we conceptualized land management function as consisting of land planning, land organising, land controlling, and land leadership. This conceptual model for land management abstracts from the functional definition of management and is represented in Figure 2. 


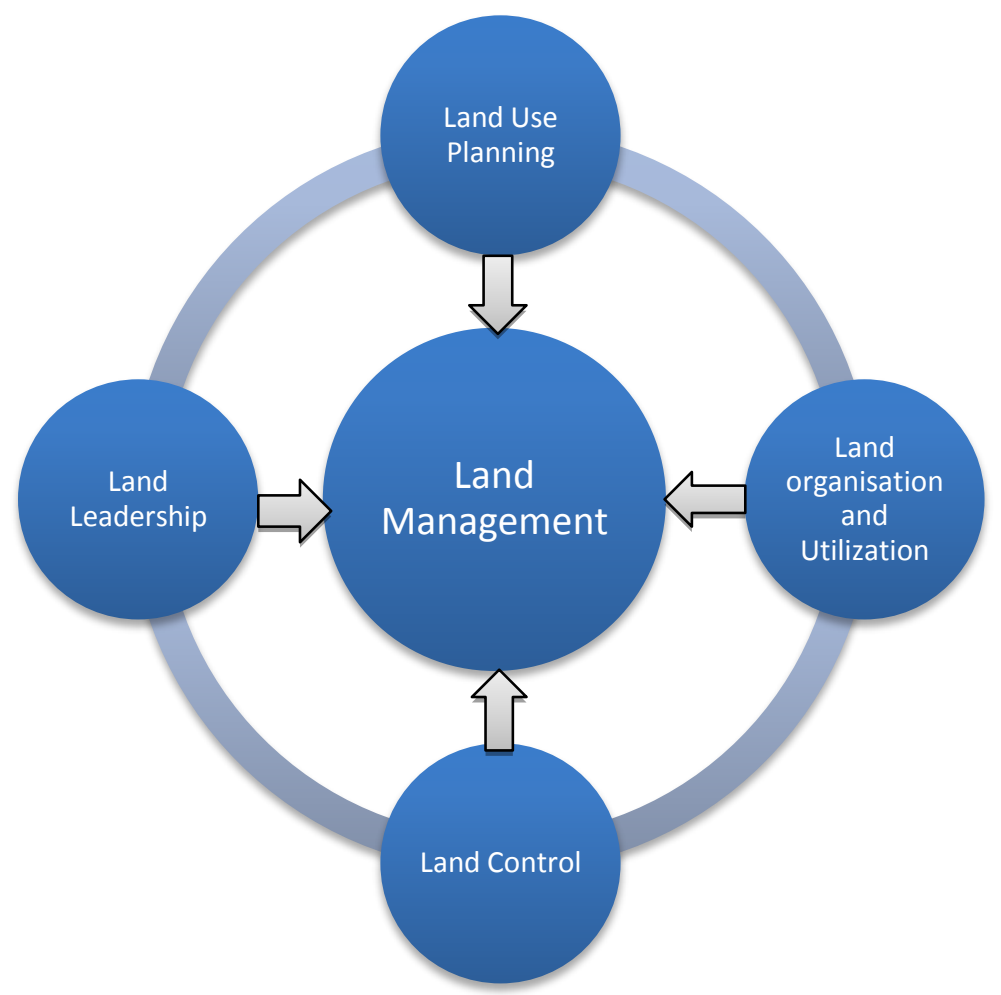

Figure 2: Conceptual Model for Land Management

Source: Conceptualized by authors based on the functional definition of management

As depicted in the model, the four main functions of land management are summarized in Table 1 which provides a description of the various functions and the relevant institutions responsible for performing those functions in Ghana. Referring to Table 1 we note that traditional leaders are mainly responsible for land organisation and land control.

Table 1: Functions of Land Management and the Responsible Stakeholders in Ghana

\begin{tabular}{|c|c|c|}
\hline Land Management Function & Description & Key Stakeholders Responsible \\
\hline Land Leadership & $\begin{array}{l}\text { It entails setting the objectives, policies, } \\
\text { enactments/legislations, supervisory } \\
\text { oversight, directives, and coordination } \\
\text { for sustainable land utilization. }\end{array}$ & $\begin{array}{l}\text { - Ministry of Lands and Natural Resources } \\
\text { - Ministry of Local Government and Rural } \\
\text { - } \quad \text { Mevelopment and } \\
\end{array}$ \\
\hline Land Use Planning & $\begin{array}{l}\text { It entails looking ahead and charting a } \\
\text { course for the sustainable use of land }\end{array}$ & $\begin{array}{l}\text { - } \text { District and Municipal Assemblies } \\
\text { - } \quad \text { Town and Country Planning } \\
\text { - Environmental Protection Agency }\end{array}$ \\
\hline Land Organisation & $\begin{array}{l}\text { It entails administration, mobilization, } \\
\text { and arrangements for the appropriate } \\
\text { use of land. }\end{array}$ & $\begin{array}{l}\text { - Lands Commission } \\
\text { - } \text { Office of the Administrator of Stool Lands } \\
\text { Commission } \\
\text { - Traditional leadership' structures designed } \\
\text { for the customary administration of stool, } \\
\text { skin, or community-owned land }\end{array}$ \\
\hline Land Use Control & $\begin{array}{l}\text { It entails checking and aligning the } \\
\text { actual use of land to its intended use. } \\
\text { Land use control occurs at two levels: } \\
\text { at the point of acquisition/purchase/sale } \\
\text { and at the point of use. }\end{array}$ & $\begin{array}{l}\text { Control at the point of acquisition: Traditional } \\
\text { authorities, clan/family heads, the Lands } \\
\text { Commission } \\
\text { Control at the point of use: District Assemblies, } \\
\text { the general public/community members }\end{array}$ \\
\hline
\end{tabular}

Source: Authors' conceptualization and compilation 


\section{METHODOLOGY}

\subsection{Research Design}

The multiple goals of the research were addressed through a qualitative research design involving interviews. The interviews were conducted to two select groups: the land sector agencies on one hand and the traditional leaders on the other. The interviews with the traditional leaders were to ascertain the level of knowledge they have about the relevant land policies and laws as well as the functions of the land sector agencies and institutions with whom they are expected to collaborate. Additionally, the interview with traditional aim at gauging the extent to which they involve the land sector agencies in their land management activities. The interviews with the land sector agencies also sought to understand the extent to which they involve the traditional leaders in the land management process. In addition to the interviews, the two main documents defining the framework for land management in the country were reviewed to describe the expected working relationship between the land sector agencies and traditional leaders.

\subsection{Study Setting}

Since this study was in response to the alleged behaviours of some traditional leaders in the oil and gas (Western) Region, we focused only on the Municipal and District Assemblies located along the coast of the Region. These were the areas believed to have experienced a lot of land transaction associated with the oil discovery because of their perceived proximity to the oil rig. In all, four District Assemblies and one Municipal Assembly were covered. The Districts covered included Jomoro, Elembele, Ahanta West, and Shama with Nzema East being the only Municipal Assembly included. Three communities each represented by their traditional leaders were purposively selected taking into consideration the amount of land transaction taking place in those areas. The justification for using purposive sampling lies in the argument by Descombe (2007) that when researcher(s) already know something about the specific study population, they must intentionally select particular cases because they are more likely to provide rich and valuable information or data. In Sekondi-Takoradi Metropolitan Assembly, the Land Sector Agencies were interviewed.

\subsection{Instrumentation}

Two instruments were self-developed and validated for the data collection. The first was a semi-structured interview guide for the traditional leaders and the second was also an interview guide for the land sector agencies. The semi-structured interview guide for the traditional leaders sought to assess the knowledge of traditional leaders about the existing framework for managing land in the country and the study area and to gauge the extent of involvement of land sector agencies by the traditional leaders in the land management process. Thus the interview guide covered four main areas: the demographic characteristics of the traditional leaders, knowledge about the existing policies and legislations for land management, involvement of land sector agencies by the traditional leaders in land management and finally possible ways of improving customary land management. The second interview guide sought to corroborate the working relationship between the land sector agencies and the traditional leaders as identified in our review of the Lands Commission Act 2008 (Act 767) and the National Land Policy document of 1999.

\subsection{Ethical Considerations}

As a good research practice, all protocols and ethical issues were observed to the fullest before, during, and after the data collection. Respondents were provided adequate information about the project, the financiers, and the potential fallouts of the project. They were also assured anonymity, confidentiality, respect, and trust. Voluntary consents were obtained from all participants.

\subsection{Validity and Reliability}

In order to ensure that the information collected from the traditional leaders reflected their true perspectives, the interviews were conducted in their setting and local dialect. The interviews were audio recorded to 
avoid reliance on the researchers' capability to recollect what took place during the interview process. The audio tapes were given to professional transcribes well-versed in the local languages in which the interviews were conducted for verbatim transcription. After the transcription by the experts, the researchers then applied one of the procedures suggested by Gibbs (2007) to check for reliability by allowing the interviewers to go through the transcriptions and comparing them to the audio tapes they recorded to ensure accuracy and no obvious mistakes made during the transcription.

\subsection{Data Management}

Before proceeding to analyse the data, the raw data was subjected to proper treatment to ensure validity and reliability. It is worth stating that, inasmuch as data management will ensure validity and reliability; it does not compensate for a poorly designed study.

\subsection{Data Analysis}

The researchers followed a systematic process of analysing the transcripts manually. We read through all the transcripts carefully and thoroughly to obtain a general sense of the data and to glean some information from it. Combining the information we got from the reading of the transcripts with the research questions, we developed sub topics which were now abbreviated as codes. With the codes in mind, the transcripts were read again this time marking the appropriate segments into categories. The data belonging to each category was then assembled and analysed. To minimize subjectivity in our interpretation and ensure the accuracy or validity of the findings, we took the preliminary findings back to the participants for validation or otherwise. Presenting the preliminary finding to the participants focus group, the findings were approved as accurate.

\section{FINDINGS AND DISCUSSIONS}

\subsection{Brief Profile of Traditional Leaders Interviewed}

In all, fifteen (15) traditional leaders participated in this research. Out of this number, five (5) were female traditional leaders and the remaining ten (10) were males. On average, the participants had been in their leadership roles for their respective communities for nearly nine years. In terms of educational level, only one of the traditional leaders did not have any formal education; one had a $\mathrm{PhD}$; another one person had a degree; four had secondarylevel education and rest either ending at the primary level or middle school level.

\subsection{Existing National Framework for Land Management in Ghana}

At the time of this research, there were two major provisions that governed land management in Ghana and for that matter the study area. These were the National Land Policy (issued in 1999) and the Lands Commission Act 2008 (Act 767). While the National Land Policy was issued in recognition of the general indiscipline in the land market and to provide a panacea that will solve or curtail land-related problems (such as land encroachments, multiple land sales, use of unapproved development schemes, haphazard development, indeterminate boundaries of customary-owned lands arising from lack of reliable maps and plans, weak land administration system, and conflicting land uses, such as, the activities of mining companies among others), the current Lands Commission Act 2008 (Act 767), was promulgated to (1) promote the judicious use of land by the society and ensure that land use is in accordance with sustainable management principles and maintenance of a sound ecosystem; and (2) ensure that land development is effected in conformity with the nation's development goals.

Thirteen years after the National Land Policy came into force, some of the problems in the land sector still persist. Our interviews with the traditional leaders point out that:

1. Land boundary identification is still done with reference to physical landmarks such as hills, watercourses, trees, anthills, hills, and mountains resulting in indeterminate boundaries and consequently land encroachment and conflicts. 
2. Ownership data regarding land in most of the communities in the study area are generally deduced from memory and tracing of ancestral lineage. Land ownership is not established through the nationallyapproved procedures for documentation because of two principal reasons:

a. delays in the processing of land documents and

b. $\quad$ alleged high cost of service charges

3. There is still non-compliance with land use plans partly because the traditional authorities are oblivious of these plans or apathetic towards its enforcement because of their non-involvement in the planning process.

\subsection{Knowledge of Traditional Leaders about the Existing Framework for Land Management}

The traditional leaders narrated through the interviews that there are no established structures within the traditional system that trains them on land management. What they are taught to believe is that land is a spiritual gift from the Creator of the universe to be used by the living, preserved for the unborn, and protected by the dead/ancestors. In line with this belief, the traditional leaders asserted that they manage land through customary practices and belief systems which are undocumented but handed down from one generation to another. Commenting on the efficacy of this system of managing land, most of the traditional leaders believed that the system was becoming inefficacious partly as result of western religion and modernity.

With regards to knowledge about the National Land Policy and legislations on land management, nearly all the traditional leaders had very limited or no knowledge at all about these provisions. Only one of the traditional leaders demonstrated knowledge about the existing National Land Policy; the rest were ignorant of this important document that sets the national agenda for land management. All the traditional leaders said they know of the Lands Commission but the overwhelming majority (14 out of the 15) again said they know nothing about the Act establishing the Commission but have little knowledge about its functions and divisions. The limited knowledge about these documents according to some of the traditional leaders was attributable to the fact that they are not made available to them. Indeed, one of the traditional leaders remarked that "how can we know about the National Land Policy if it is not distributed to us." For some others whose levels of education were low, they attributed their scant knowledge to the fact that these documents were written in English and therefore they could not read and understand them.

\subsection{Involvement of Traditional Leaders in Land Management}

To ascertain the level of involvement of traditional leaders in land management, the researchers investigated the involvement of traditional leaders in land management from two standpoints: (1) as they are enshrined in the national policy document(s) and legislations and (2) as they exist on the ground. A review of the National Land Policy document and the Lands Commission Act governing land management in the Ghana shows that ample provisions exist to govern land management. These provisions have also given due recognition for the involvement of traditional leaders in the land management process. For example in the National Land Policy recognizes the involvement of traditional leaders by describing the system of land administration being governed by customary practices and legislations; where the customary practices are from the traditional leaders. A critical examination of the Lands Commission Act 2008 (Act 767), also indicate that ample provisions have been made for the involvement of traditional leaders by the Commission in the delivery of its functions. We catalogue some of the empirical referents and analysis as follows.

As a first step towards ensuring the involvement of traditional leaders in the land management, Act 767 mandates the Commission to have a representative of the National and Regional House of Chiefs on its Commission. Categorically, Section 8 subsection 1(b) (i), states that the Commission shall have one representative of, nominated by, the National House of Chiefs. Similarly, Section 9 subsection b (i) also mandates the Regional Lands Commission to have one nominee and a representative of the Regional House of Chiefs. These representatives are expected to bring to bear on the Commission the concerns of the traditional authorities and to offer suggestions that will improve land management in the country particularly stool or skin lands.

Besides ensuring that chiefs or traditional leaders are represented on the Commission, the Act expressly states in Section 7 subsection 1(c) that, the Commission shall collaborate and coordinate with "structures design for 
the customary administration of stool, skin, family or community-owned land or any other land." More importantly, the Act also requires a consultative working relationship between the Regional Lands Commission and traditional authorities especially in matters concerning stool lands. This is clearly stated in Section 10 subsection 4 that, "The Regional Lands Commission shall consult with the stools and other traditional authorities in all matters relating to the administration and development of stool land and shall make available to them all relevant information and data."

Contrary to the view that Act 767 seeks to involve traditional authorities in land management, some critics have argued that, the Act is limiting the powers of the traditional authorities. The basis of this argument is related to the provision of Section 10 (2) which states inter alia that "There shall be no disposition or development of any stool land unless the Regional Lands Commission of the Region in which the land is situated has certified that the disposition or development is consistent with the development plan drawn up or approved by the planning authority for the area concerned." From a neutral position, we argue that whichever way this provision is interpreted, there is no gainsaying the fact that, it seeks to prevent haphazard land development which will pose problems and threat to people in times of rains and other calamities. In management, planning is very important: it minimizes the probability of failure and increases the chances of success. Thus, Section 10 (2) stated above seeks to ensure that development plans drawn up for the areas are adhered to.

With regards to the practical involvement of traditional leaders in land management, the researchers gathered from the interview with the Lands Commission that they do have the Regional House of Chiefs advising on land matters through its representative on the Commission. The Commission however conceded that it has not done much in the area of educating the traditional leaders on how they can partner each other to effectively manage land.

On the part of traditional leaders, the researchers gathered that due to the limited knowledge that the leaders have about the land sector agencies, they were not involving them in their land management function. The traditional leaders who mention that they had involved the Lands Commission expressed discontent about the delays in the processing of land documents leading to high cost of service charges. There were also those traditional leaders who did not involve the Lands Commission in their land transactions particularly because they perceived them to be limiting their power. For instance, when asked to describe the relationship between the Lands Commission and the Chiefs, one of the chiefs gave this as his response: "The Lands Commission is there for government and those who want to register their land while the traditional leaders are the landowners. Thus, one should not exercise control or some kind of power over the other."

\section{CONCLUSIONS AND RECOMMENDATIONS}

Since the discovery of oil in commercial quantities in the Western Region of Ghana and the attendant media reports of some traditional leaders rushing to sell land, there has been a renewed interest in land management in the area. The purpose of this study was to review the existing framework for managing land in Ghana and for that matter the Western Region with special interest on assessing the knowledge of traditional leaders about this framework with the view to determining the extent of involvement of the traditional leaders in the land management process. Combining desk review with interviews of key stakeholders in land management, we found that Ghana abounds with policies and legislations for managing land. However, the results from the analysis of interviews show that traditional leaders in the study area have limited knowledge about the national framework for land management. They do not know about the National Land Policy and the functions of key government institutions established to administer and manage land. This in the researchers' view has hampered land management effort because the lack of knowledge has rather slowed the process of participation and involvement needed to enhance and facilitate land management. Thus, the researchers are of the view that to enhance customary land management, regular and continuous education should be provided to the traditional leaders or customary land owners. In this regard, there may be the need for the establishment of a Centre for Training Traditional leaders.

\section{AUTHOR INFORMATION}

Prof. Joshua Alabi, University of Professional Studies, Dean of Management Studies \& Ag Deputy Director, LG 149 Legon, Accra, Ghana. E-mail: Jalabius@ gmail.com (Corresponding author) 
Dr. Goski Alabi, University of Professional Studies, Dean, School of Research and Graduate Studies, LG 149 Legon, Accra, Ghana. E-mail: goski.alabi@gmail.com

Ibrahim Mohammed, University of Professional Studies, School of Research and Graduate Studies, LG 149 Legon, Accra, Ghana.

\section{REFERENCES}

1. Boampong, A. (2009): Economic justice now! Demands the youth of Western Ghana. Retrieved 24 Sept. 2009 from http://www.modernghana.com

2. Britton, W., Davies, K,\& Johnson, T. (1980). Modern methods of valuation of land, houses and buildings. The Pitman Press, Bath, Great Britain.

3. Descombe, M. (2007). The good research guide: For small-scale social research projects ( $3^{\text {rd }}$ ed.). Maidenhead: Open University Press.

4. $\quad$ Enemark, S., Williamson, I., \& Wallace, J. (2005). Building modern land administration systems in developed economies. Journal of Spatial Science, 50(2), 51-68.

5. FAO \& UNEP (1999). The future of our land: Facing the challenge. Guidelines for integrated planning for sustainable management of land resources.

6. Gibbs, G. (2007). Analyzing qualitative data. (Book 6 of The Sage Qualitative Research Kit). London: Sage.

7. $\quad$ GoG (2008). Lands Commission Act 2008 (Act 767).

8. Kalantari, M., Rjabifard, A., \& Bennet, R. (2010). Modern land administration; technical characteristics. FIG Congress on Facing the Challenges-Building the Capacity, 11-16 April 2010, Sydney, Australia

9. Kasanga, K., \& Kotey, N. A. (2001) Land management in Ghana: Building on tradition and modernity. London: International Institute for Environment and Development.

10. Larsson, G. (1991). Land registration and cadastral systems: Tools for land information and management. Harlow, Essex, England: Longman Scientific and Technical, New York: Wiley, ISBN 0-582-08952-2, 175.

11. Ministry of Lands and Forestry (1999). National Land Policy. Accra

12. UNECE (1996). Land administration guidelines, UNECE, Geneva

13. UNECE (2005). Land administration in the UNECE region: Development trends and main principles U. I. Service. Geneva, United Nations Economic Commission for Europe: 112.

14. World Bank (2006). Sustainable land management: Challenges, opportunities, and trade-offs. Washington: The international bank for reconstruction and development. 